\title{
Assessing emergency situations and their aftermath in urban areas: The EMRAS II Urban Areas Working Group
}

\author{
K.M. Thiessen ${ }^{1}$, K.G. Andersson ${ }^{2}$, V. Berkovskyy ${ }^{3}$, T.W. Charnock ${ }^{4}$, \\ S.L. Chouhan ${ }^{5}$, G. de With ${ }^{6}$, J. Dúran ${ }^{7}$, V. Fuka ${ }^{8}$, J. Helebrant ${ }^{9}$, J. Hůlka ${ }^{9}$, \\ W.T. Hwang ${ }^{10}$, P. Kuča ${ }^{9}$, F. Mancini ${ }^{11}$, E. Navarro ${ }^{12}$, R. Periáñez ${ }^{13}$, \\ Z. Prouza $^{9}$, G. Sdouz ${ }^{14}$, J. Tomás ${ }^{15}$, D. Trifunović ${ }^{16}$, L. Urso ${ }^{17}$ \\ and $\mathrm{H}$. Walter ${ }^{18}$ \\ ${ }^{1}$ SENES Oak Ridge, Inc., 102 Donner Drive, Oak Ridge, Tennessee 37830, USA \\ ${ }^{2}$ Risø-DTU National Laboratory for Sustainable Energy, P.O. Box 49, DK-4000 Roskilde, \\ Denmark \\ ${ }^{3}$ International Atomic Energy Agency, P.O. Box 100, 1400 Vienna, Austria \\ ${ }^{4}$ Health Protection Agency, Chilton, Didcot, Oxfordshire OX11 ORQ, UK \\ ${ }^{5}$ Atomic Energy of Canada Limited, KOJ 1JO Chalk River, Ontario, Canada \\ ${ }^{6}$ Nuclear Research \& Consultancy Group, P.O. Box 9034, 6800 ES Arnhem, The Netherlands \\ ${ }^{7}$ VúJE Inc., Okruzna 5, 91864 Trnava, Slovakia \\ ${ }^{8}$ Charles University, V. Holesovickah 2, 18000 Prague 8, Czech Republic \\ ${ }^{9}$ National Radiation Protection Institute, Bartoskova 28, 14000 Prague 4, Czech Republic \\ ${ }^{10}$ Korea Atomic Energy Research Institute, 150 Dukjin-Dong, Yusong, 305-600 Daejeon, \\ Republic of Korea \\ ${ }^{11}$ SOGIN S.p.A., Via Torino 6, 00184 Roma, Italy \\ ${ }^{12}$ Institut de Radioprotection et de Sûreté Nucléaire, BP. 17, 92262 Fontenay-aux-Roses, \\ Cedex, France \\ ${ }^{13}$ ETSIA, Universidad de Sevilla, Ctra Utrera km 1, 41013 Sevilla, Spain \\ ${ }^{14}$ Austrian Institute of Technology $\mathrm{GmbH}, 2444$ Seibersdorf, Austria \\ ${ }^{15}$ Centro de Protección e Higiene de las Radiaciones, A.P. 6195, La Habana 10600, \\ Cuba \\ ${ }^{16}$ State Office for Radiological and Nuclear Safety, Frankopanska 11, HR-10000 Zagreb, \\ Croatia \\ ${ }^{17}$ Helmholtz-Zentrum München GmbH, Postfach 1129, 85764 Neuherberg, Germany \\ ${ }^{18}$ Bundesamt für Strahlenschutz, 85764 Oberschleißheim, Germany
}

\begin{abstract}
The Urban Areas Working Group is part of the International Atomic Energy Agency's EMRAS II (Environmental Modelling for Radiation Safety) Programme. The goal of this Working Group is to test and improve the capabilities of models used in assessment of radioactive contamination in urban settings, including dispersion and deposition events, short- and long-term contaminant redistribution following deposition events, and potential countermeasures or remediation efforts for reducing human exposures and doses. The Working Group has developed three modeling exercises, which are designed to permit intercomparison of model predictions and, in one case, comparison of model predictions with measurements. This paper describes the scenarios and provides comparisons of initial modeling results. Reasons for similarities and discrepancies among model predictions are discussed in terms of the modeling approaches, models, and parameter values used by different assessors. Preliminary conclusions emphasize the value of explaining individual approaches and the importance of understanding the effects of different assumptions and parameter values on the modeling results.
\end{abstract}


Table 1. Summary information for the field tests.

\begin{tabular}{|l|c|c|c|c|}
\hline & Test 1 & Test 2 & Test 3 & Test 4 \\
\hline Date & 6 December 2007 & 15 May 2008 & 5 May 2009 & 14 July 2009 \\
\hline Activity (MBq) & 780 & 1058 & 1222 & 1088 \\
\hline Volume of activity & $1.5 \mathrm{~L}$ & $6 \mathrm{~mL}$ & $6 \mathrm{~mL}$ & $6 \mathrm{~mL}$ \\
\hline $\begin{array}{l}\text { Type and amount of } \\
\text { explosive used }\end{array}$ & Permon 10T, & Vesuvit TN, & Permon 10T, & Permon 10T, \\
$20 \mathrm{~g}$ & $350 \mathrm{~g}$ & 350 g \\
\hline Temperature $\left({ }^{\circ} \mathrm{C}\right)$ & $30 \mathrm{~g}$ & $22.2-22.3$ & $9.7-10.4$ & $25.4-25.6$ \\
\hline $\begin{array}{l}\text { Wind speed at } 2 \mathrm{~m} \\
\text { height }(\mathrm{km} / \mathrm{h})\end{array}$ & $7.9-16.2$ & $1.2-6.6$ & $1.4-16.2$ & $0-3.2$ \\
\hline $\begin{array}{l}\text { Wind direction } \\
\text { (blowing from) }\end{array}$ & SW-SSW & S-SSW & SW-NNE & WSW-SSE \\
\hline
\end{tabular}

\section{INTRODUCTION}

The Urban Areas Working Group was organized within the International Atomic Energy Agency's EMRAS II (Environmental Modelling for Radiation Safety) Programme, as part of a theme entitled "Approaches for Assessing Emergency Situations." The Working Group is building on the work done by the Urban Remediation Working Group of the first phase of the EMRAS Programme [1-5]. The goal of the Urban Areas Working Group is to test and improve the capabilities of models used in assessment of radioactive contamination in urban settings, including dispersion and deposition events, short- and long-term contaminant redistribution following deposition events, and potential countermeasures or remediation efforts for reducing human exposures and doses.

The Urban Areas Working Group has developed three modeling exercises, which are designed to permit intercomparison of model predictions. In one case, comparison of model predictions with measurements is also possible for several endpoints. Reasons for similarities and discrepancies among model predictions are discussed in terms of the modeling approaches, models, and parameter values used by different assessors. An important objective is the identification of areas in which models or selection of parameter values could be improved.

\section{SHORT-RANGE ATMOSPHERIC DISPERSION EXERCISE}

The short-range atmospheric dispersion exercise is based on data from several field tests performed by the National Radiation Protection Institute on a test area belonging to the National Institute for Nuclear, Chemical and Biological Protection in Kamenná, near Prague, Czech Republic [6]. The exercise permits comparison of model predictions with measurements of surface contamination, time-integrated air concentrations, and dose rates, up to $50 \mathrm{~m}$ downwind. Intercomparisons of model predictions are used for distances up to $2000 \mathrm{~m}$ downwind and for additional modeling endpoints.

In these field tests, a short-lived radionuclide (Tc-99m) in liquid form was spread by detonation of a small amount of explosive in an open field (flat terrain) or in an open field with some simulated structures. Measurements included dose rates, surface contamination, air concentrations, particle size distributions, time-distributions of dust particles in air, and thermo-camera snapshots. The test area was selected for a stable wind direction under usual meteorological conditions.

Four individual field tests were used in the exercise; selected initial conditions for these tests are summarized in Table 1. Participants in the modeling exercise were asked to submit predictions for surface contamination and dose rates as a function of distance, air concentrations as a function of height and distance. Participants were provided with all available measurements for the first two tests, to permit an opportunity for calibration of models if desired. For the third and fourth tests, participants were asked to submit model predictions before having access to measurements of the modeling endpoints. 
Table 2. Comparison of models and selected parameters used in the short-range atmospheric dispersion exercise.

\begin{tabular}{|c|c|c|c|c|}
\hline $\begin{array}{l}\text { Model } \\
\text { (Participant) }\end{array}$ & $\begin{array}{l}\text { Type of } \\
\text { model }\end{array}$ & $\begin{array}{l}\text { Stability } \\
\text { classes }\end{array}$ & $\begin{array}{l}\text { Wind speed } \\
\qquad(\mathrm{m} / \mathrm{s})\end{array}$ & $\begin{array}{l}\text { Dry deposition } \\
\text { velocity }(\mathrm{m} / \mathrm{s})\end{array}$ \\
\hline $\begin{array}{l}\text { ADDAM/CSA- } \\
\text { ERM (Chouhan) }\end{array}$ & Gaussian & $\begin{array}{l}\text { Test 3: Class C } \\
\text { Test 4: Class A }\end{array}$ & $\begin{array}{c}\text { Test } 3: 2.7 \\
\text { Test } 4: 0.726\end{array}$ & $1 \mathrm{E}-1$ \\
\hline $\begin{array}{l}\text { Hotspot } 2.07 .1 \\
\text { (Charnock) }\end{array}$ & Gaussian & $\begin{array}{l}\text { Test 3: Class D } \\
\text { Test 4: Class C }\end{array}$ & $\begin{array}{l}\text { Test 3: } 1.5 \\
\text { Test 4: } 0.4\end{array}$ & $\begin{array}{l}\text { Respirable fraction, 1E-4; } \\
\text { nonrespirable fraction, 4E-1 }\end{array}$ \\
\hline $\begin{array}{l}\text { Hotspot } \\
\text { (Trifunović) }\end{array}$ & Gaussian & $\begin{array}{l}\text { Test 2: Class B } \\
\text { Test 3: Class D } \\
\text { Test 4: Class C }\end{array}$ & $\begin{array}{l}\text { Test 2: } 0.6 \\
\text { Test 3: } 1.3 \\
\text { Test : } 0.1\end{array}$ & $\begin{array}{l}\text { Respirable fraction, } \\
\text { 8E-4 }\end{array}$ \\
\hline $\begin{array}{l}\text { RDD_MMC } \\
\text { (Ľúran) }\end{array}$ & Lagrangian & $\begin{array}{l}\text { Test 1: Class C } \\
\text { Test 2: Class A } \\
\text { Test 3: Class B } \\
\text { Test 4: Class A }\end{array}$ & $\begin{array}{l}\text { Test } 1: 4.00 \\
\text { Test 2: } 0.59 \\
\text { Test 3: } 1.30 \\
\text { Test 4: } 0.20\end{array}$ & $\begin{array}{c}0.2 \mu \mathrm{m}, 5.0 \mathrm{E}-3 \\
1.0 \mu \mathrm{m}, 1.5 \mathrm{E}-4 \\
8.0 \mu \mathrm{m}, 1.0 \mathrm{E}-3 \\
20.0 \mu \mathrm{m}, 8.0 \mathrm{E}-3\end{array}$ \\
\hline $\begin{array}{l}\text { University of } \\
\text { Seville (Periáñez) }\end{array}$ & Lagrangian & Not applicable & $\begin{array}{c}\text { Time-dependent } \\
\text { measurements }\end{array}$ & Not applicable \\
\hline $\begin{array}{l}\text { LASAIR } \\
\text { (Walter) }\end{array}$ & Lagrangian & $\begin{array}{c}\text { Test 1: Class D } \\
\text { Test 2: Class B-C } \\
\text { Test 3: Class D } \\
\text { Test 4: Class C }\end{array}$ & $\begin{array}{c}\text { Test } 1: 0-6.3 \\
\text { Test } 2: 0.28-1.85 \\
\text { Test } 3: 0.9-7.2 \\
\text { Test : } 0-4.9\end{array}$ & $\begin{array}{c}<0.39 \mu \mathrm{m}, 5 \mathrm{E}-5 \\
0.39-1.3 \mu \mathrm{m}, 1.5 \mathrm{E}-5 \\
1.3-10.2 \mu \mathrm{m}, 1 \mathrm{E}-3 \\
>10.2 \mu \mathrm{m}, 8 \mathrm{E}-3\end{array}$ \\
\hline $\begin{array}{l}\text { CFD } \\
\text { (de With) }\end{array}$ & $\begin{array}{l}\text { Computational } \\
\text { fluid dynamics }\end{array}$ & Not applicable & $\begin{array}{l}\text { Steady-state } \\
\text { conditions } \\
\text { (mean values) }\end{array}$ & $\begin{array}{c}0.2 \mu \mathrm{m}, 5.0 \mathrm{E}-5 \\
1.0 \mu \mathrm{m}, 1.5 \mathrm{E}-4 \\
8.0 \mu \mathrm{m}, 1.0 \mathrm{E}-3 \\
20.0 \mu \mathrm{m}, 8.0 \mathrm{E}-3\end{array}$ \\
\hline $\begin{array}{l}\text { CLMM } \\
\text { (Fuka) }\end{array}$ & $\begin{array}{l}\text { Atmospheric } \\
\text { computational } \\
\text { fluid dynamics }\end{array}$ & Not applicable & $\begin{array}{c}\text { Test } 1: 3.8 \\
\text { Test } 2: 0.77 \\
\text { Test } 3: 2.3 \\
\text { Test }: 0.4\end{array}$ & Not applicable \\
\hline
\end{tabular}

Eight participants have submitted preliminary calculations for the short-range exercise. Table 2 summarizes selected information about the models and their parameterization. The models represented three main types of approaches to modeling atmospheric dispersion and had been developed for a variety of purposes. Although there was much discussion about standardizing some of the input information, participants generally used their own interpretations of the information. Examples of predicted deposition down the center line of the grid or plume are shown in Fig. 1 for Tests 3 and 4. Results for Test 3 were generally closer to each other and to the measurements than those for Test 4 , which had less stable wind conditions and downwind obstacles.

\section{MID-RANGE ATMOSPHERIC DISPERSION EXERCISE}

The mid-range atmospheric dispersion exercise is based on a hypothetical accident at a nuclear power plant and the resulting predicted deposition in urban environments up to $70 \mathrm{~km}$ downwind. The scenario assumes a 1-hour release from a rupture of a steam generator tube (based on an accident scenario developed by ISRN) and uses actual geographic and meteorological information for the Trillo nuclear power plant in central Spain. The exercise considers two sets of atmospheric stability conditions, stable (Class E) and neutral (Class D), and uses wind fields $10 \mathrm{~m}$ above the ground. The radionuclides are assumed to be released as gas, with a release height of $50 \mathrm{~m}$. Only dry deposition is considered. Although 

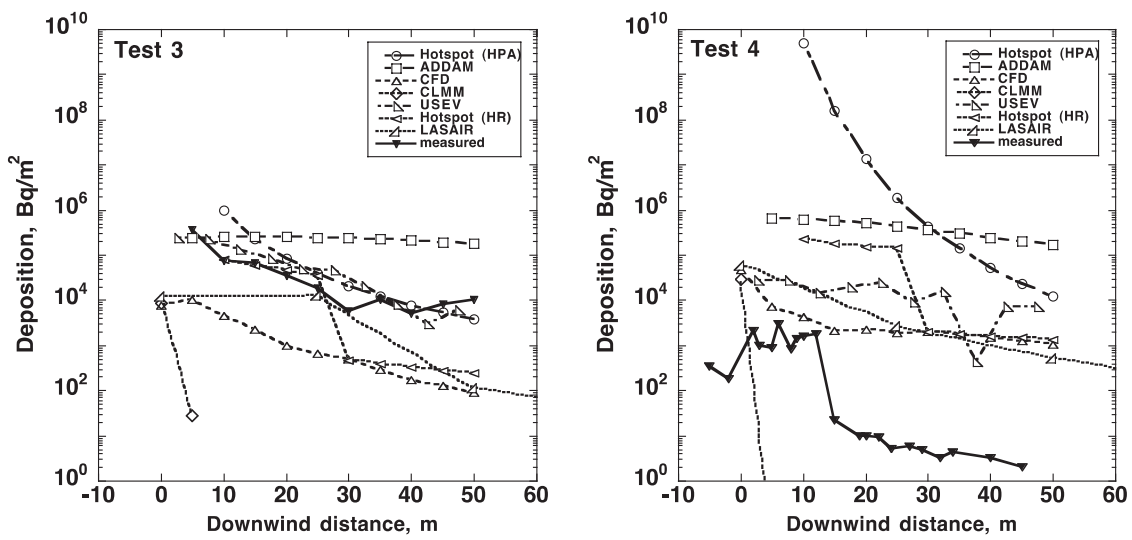

Figure 1. Examples of model predictions and measured deposition down the center line of the grid $(\mathrm{x}=0$; CFD, CLMM, USEV, LASAIR, measurements) or the plume center line (ADDAM, Hotspot) for Tests 3 and 4.

Table 3. Comparison of models and parameters used in the mid-range atmospheric dispersion exercise.

\begin{tabular}{|c|c|c|c|c|}
\hline $\begin{array}{l}\text { Model } \\
\text { (Participant) }\end{array}$ & $\begin{array}{l}\text { Type of } \\
\text { model }\end{array}$ & $\begin{array}{c}\text { Release } \\
\text { step }\end{array}$ & $\begin{array}{l}\text { Wind } \\
\text { speed }\end{array}$ & $\begin{array}{c}\text { Dry deposition } \\
\text { velocity }(\mathrm{m} / \mathrm{s})\end{array}$ \\
\hline $\begin{array}{l}\text { ADDAM } \\
\text { (Chouhan) }\end{array}$ & Gaussian & $1 \mathrm{~h}$ & $\begin{array}{l}\text { wind vectors summed } \\
\text { outside the code }\end{array}$ & $\begin{array}{l}\text { Cs-137, 0.01 } \\
\text { I- } 131,0.008\end{array}$ \\
\hline $\begin{array}{l}\text { Hotspot } \\
\text { (Trifunović) }\end{array}$ & Gaussian & $1 \mathrm{~h}$ & $\begin{array}{l}\text { Class E: } 3.0 \mathrm{~m} / \mathrm{s} \\
\text { Class D: } 6.0 \mathrm{~m} / \mathrm{s}\end{array}$ & $\begin{array}{c}\text { Cs-137, 0.0004 } \\
\text { I-131, 0.0022 }\end{array}$ \\
\hline $\begin{array}{l}\text { JRODOS } \\
\text { (Sdouz) }\end{array}$ & $\begin{array}{c}\text { Gaussian }+ \\
\text { simplified puff }\end{array}$ & $30 \mathrm{~min}$ & $\begin{array}{l}\text { wind fields } \\
\text { as provided }\end{array}$ & $\begin{array}{l}\text { calculated } \\
\text { internally }\end{array}$ \\
\hline $\begin{array}{l}\text { RASCAL 3.0.3 } \\
\text { (Mancini) }\end{array}$ & $\begin{array}{c}\text { Gaussian plume and } \\
\text { Lagrangian puff }\end{array}$ & $1 \mathrm{~h}$ & $\begin{array}{l}\text { limited number of } \\
\text { wind vectors used }\end{array}$ & $\begin{array}{c}\text { Cs-137, } 0.003 \\
\mathrm{I}-131,0.003\end{array}$ \\
\hline $\begin{array}{l}\text { University of } \\
\text { Seville (Periáñez) }\end{array}$ & Lagrangian & $1 \mathrm{~min}$ & $\begin{array}{l}\text { wind fields } \\
\text { as provided }\end{array}$ & not applicable \\
\hline
\end{tabular}

a variety of radionuclides would be released in such a situation, for modeling purposes only two (Cs-137 and I-131) are considered. Time-dependent release rates were provided.

Participants were asked to carry out a simulation for a 10-h period and to provide estimates of deposited activity at the end of the period, time-integrated activity concentrations in air, and time series of activity concentrations in air at selected locations. This is a model intercomparison exercise for all endpoints.

Five participants have submitted preliminary calculations for the mid-range exercise. Table 3 summarizes selected information about the models and their parameterization. The models represented two main types of approaches to modeling atmospheric dispersion. Examples of predicted deposition of Cs-137 at two downwind locations are shown in Fig. 2. JRODOS was used only for the stable atmospheric conditions. RASCAL's predictions did not extend as far as Madrid. Under neutral atmospheric conditions, plumes predicted by ADDAM and the University of Seville model (not shown) missed or barely intersected Madrid.

\section{CONTAMINANT TRANSPORT AND COUNTERMEASURES EXERCISE}

The contaminant transport and countermeasures exercise starts with an assumed concentration of Co-60 or Pu-239 in air, in parts of a city (Seoul) for which detailed geographic and building information 


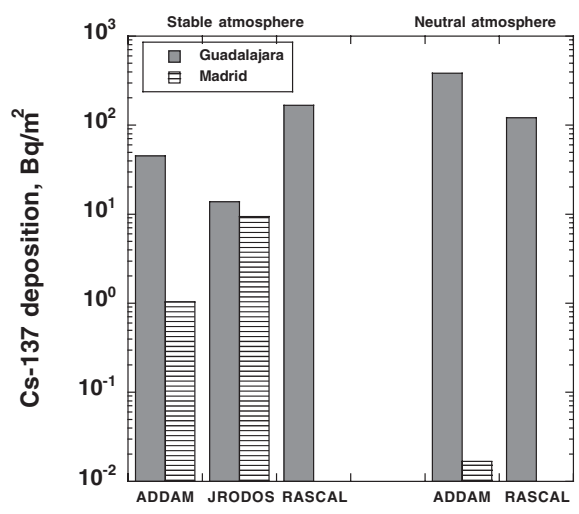

Figure 2. Examples of model predictions for deposition of Cs-137 at selected locations downwind from the Trillo NPP. Guadalajara is $46 \mathrm{~km}$ from Trillo, and Madrid is $70 \mathrm{~km}$ away.

Table 4. Comparison of models and parameters used in the contaminant transport and countermeasures exercise.

\begin{tabular}{|c|c|c|c|c|}
\hline $\begin{array}{l}\text { Model } \\
\text { (Participant) }\end{array}$ & Deposition & Weathering & $\begin{array}{c}\text { Indoor } \\
\text { contamination }\end{array}$ & Trees \\
\hline $\begin{array}{l}\text { METRO-K } \\
\text { (Hwang) }\end{array}$ & $\begin{array}{c}\text { dry deposition } \\
\text { by surface; wet } \\
\text { deposition from } \\
\text { daily rainfall and } \\
\text { washout ratio, with } \\
\text { retained fraction }\end{array}$ & $\begin{array}{l}\text { short-term and } \\
\text { long-term removal } \\
\text { rates by surface }\end{array}$ & not included & $\begin{array}{l}\text { deciduous; date } \\
\text { for leaf fall not } \\
\text { specified; deposition } \\
\text { on trees in winter } \\
10 \% \text { of deposition } \\
\text { in summer }\end{array}$ \\
\hline $\begin{array}{l}\text { ERMIN } \\
\text { (Charnock) }\end{array}$ & $\begin{array}{c}\text { deposition on } \\
\text { lawn from } \\
\text { METRO-K; other } \\
\text { surfaces relative to } \\
\text { lawn, wet or dry }\end{array}$ & $\begin{array}{c}\text { surface-specific } \\
\text { empirical weathering } \\
\text { simple empirical } \\
\text { functions; movement } \\
\text { down soil column }\end{array}$ & $\begin{array}{l}\text { included, from } \\
\text { penetration of building; } \\
\text { date for leaf fall retention } \\
\text { function for generic } \\
\text { indoor surfaces }\end{array}$ & $\begin{array}{c}\text { deciduous and } \\
\text { coniferous; specified }\end{array}$ \\
\hline $\begin{array}{l}\text { CPHR } \\
\text { (Tomás) }\end{array}$ & $\begin{array}{c}\text { dry deposition } \\
\text { velocity; washout } \\
\text { coefficient for wet } \\
\text { deposition }\end{array}$ & $\begin{array}{c}\text { half-lives } \\
\text { depending on } \\
\text { surface }\end{array}$ & $\begin{array}{l}\text { indoor air but not } \\
\text { surfaces; filtration } \\
\text { factor }\end{array}$ & $\begin{array}{c}\text { deciduous, no } \\
\text { contamination after } \\
\text { first leaf fall }\end{array}$ \\
\hline
\end{tabular}

is available. Participants were asked to predict deposition for several kinds of weather conditions (dry, light rain, and heavy rain) and for both a business area (buildings and asphalt) and a park area. Additional endpoints for model intercomparison include contamination densities, dose rates, countermeasure effectiveness, and doses for specified reference individuals.

Three participants have submitted preliminary calculations for the countermeasures exercise. Table 4 summarizes selected information about the models and their use in this exercise. Both METRO-K and CPHR started with the air concentration as provided in the scenario description. ERMIN started with the deposition on a lawn as predicted by METRO-K for a given set of conditions. Fig. 3 shows the predicted dose rate from Co-60 for an outdoor location in the business area, for a contamination event occurring under dry conditions in the summer, together with the $\%$ contributions to the dose rate from the most important surfaces. Fig. 4 shows the predicted external doses over 1 year or 5 years from a defined situation including that same outdoor location and nearby indoor locations. Fig. 4 also shows the $\%$ reduction in dose expected for several specified countermeasures. 

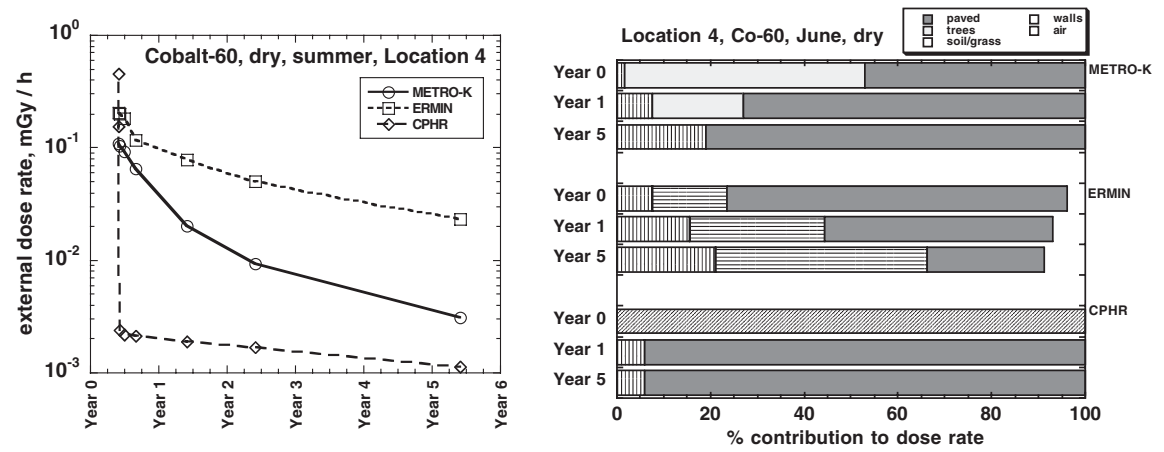

Figure 3. Predicted external dose rate (left) and \% contribution to dose rate of various surfaces (right) from Co-60 at an outdoor location in a business area, for a deposition event occurring under dry conditions during summer.
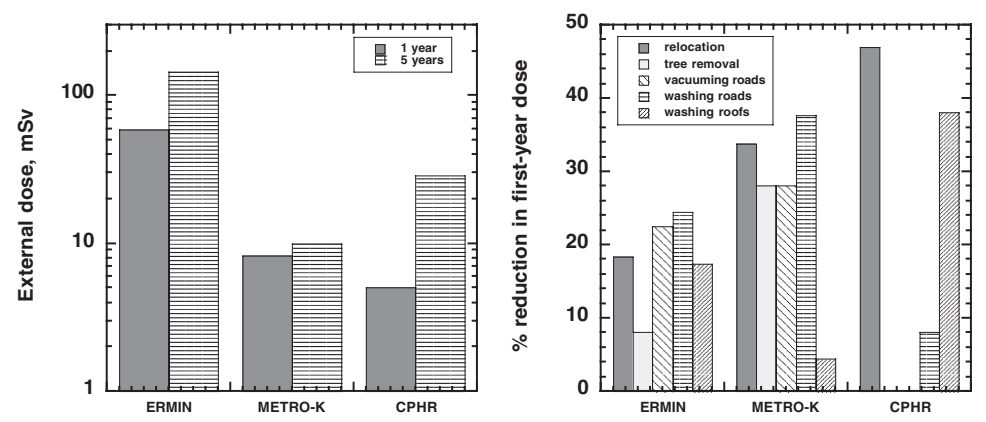

Figure 4. Predicted external dose (for a defined exposure situation) from Co-60 over 1 year or 5 years (left) assuming no action (no countermeasures), and \% reduction in predicted external dose expected over 1 year (right) assuming application of individual countermeasures.

Some differences in the results are attributable to differences in how the models handled different parts of the situation. For example, roads, trees, and soil/grass had different importance in the different models (Fig. 3); therefore, the models differed in the dose reduction achieved by countermeasures involving these surfaces (Fig. 4). The one model (CPHR) that included the contribution to external dose of the plume also predicted the highest dose reduction due to relocation.

\section{SUMMARY AND CONCLUSIONS}

For all test exercises, more detailed analysis is in progress to explain the similarities and differences among models and between model predictions and measurements. For each test exercise, participants have started with the same information, and in several cases there was considerable discussion and attempts to agree on specific input information, such as the dimensions of the initial plume for the field tests. However, differences in individual approaches and models remain. Areas of differences include the type of dispersion modeling incorporated into a code, the type of input information required by a model, components included in the model (e.g., indoor surfaces in the countermeasures models), and values selected for various parameters (e.g., size distribution of particles, deposition velocities, weathering coefficients). To understand either similarities or differences among modeling results, it is essential to explain individual approaches and to understand the effects of different assumptions and parameter values on the modeling results. 


\section{Acknowledgements}

This work has been supported in part by the Centers for Disease Control and Prevention under TKCIS Contract No. 200-2006-15969, Task Order No. 103, and TKCIS Contract No. NT3009034, Order No. JR5000091.

\section{References}

[1] International Atomic Energy Agency. In press. Environmental Modelling of Remediation of Urban Contaminated Areas. Report of the Urban Remediation Working Group of the EMRAS (Environmental Modelling for Radiation Safety) programme.

[2] Thiessen, K.M., Batandjieva, B., Andersson, K.G., Arkhipov, A., Charnock, T.W., Gallay, F., Gaschak, S., Golikov, V., Hwang, W.T., Kaiser, J.C., Kamboj, S., Steiner, M., Tomás, J., Trifunovic, D., Yu, C., Zelmer, R., Zlobenko, B. Appl. Radiat. Isot. 66(2008):1741-1744.

[3] Thiessen, K.M., Arkhipov, A., Batandjieva, B., Charnock, T.W., Gaschak, S., Golikov, V., Hwang, W.T., Tomás, J., Zlobenko, B. J. Environ. Radioact. 100(2009):413-421.

[4] Thiessen, K.M., Andersson, K.G., Batandjieva, B., Cheng, J.-J., Hwang, W.T., Kaiser, J.C., Kamboj, S., Steiner, M., Tomás, J., Trifunovic, D., Yu, C. J. Environ. Radioact. 100(2009):445455.

[5] Thiessen, K.M., Andersson, K.G., Charnock, T.W., Gallay, F. J. Environ. Radioact. 100(2009):564573.

[6] Prouza, Z. Beckova, V., Cespirova, I., Helebrant, J., Hulka, J., Kuca, P., Michalek, V., Rulik, P., Skrkal, J., Hovorka, J. Radiat. Prot. Dosimetry. 139(2010):519-531. 